\title{
PHENYLALANINE-RESTRICTED DIETS IN THE TREATMENT OF PHENYLKETONURIA
}

\author{
BY
}

\author{
J. D. BLAINEY and R. GULLIFORD \\ From the Departments of Experimental Pathology and Education, University of Birmingham, and the Metabolic \\ Research Unit, Little Bromwich Hospital, Birmingham
}

(RECEIVED FOR PUBLICATION JULY 18, 1956)

Phenylalanine restriction has been used in the treatment of the metabolic and mental disorders of phenylketonuria with conflicting results. Bickel, Gerrard and Hickmans (1953) reported the first successful treatment of a child aged $3 \frac{1}{2}$ who was observed for 12 months in hospital and at home. The biochemical abnormality of phenylpyruvic acid in the urine was corrected in this patient, but evidence of prolonged biochemical normality was not given, and, although the improvement in her mental condition was promising, prolonged psychological tests were not done. Woolf, Griffiths and Moncrieff (1955) reported studies of three further children for six to nine months, in whom satisfactory mental and biochemical improvements were found. Less conclusive advance in the mental state was observed by Armstrong and Tyler (1955) despite apparently normal biochemistry in the serum and urine in five children aged 9 months to $4 \frac{1}{2}$ years. Confusion also persists regarding the longer-term effects of phenylalanine restriction on the physical, biochemical and mental states of these children and adequate criteria of control and assessment have not been clearly defined. Some workers have used synthetic diets with pure amino-acids; others have given casein hydrolysates low in phenylalanine as the source of nitrogen. The ages of the children treated have varied considerably, and the initial degree of mental defect has not always been clearly described.

It is the purpose of the present paper to confirm that apparent biochemical normality can be obtained, with normal growth and physical development for long periods, using diets very severely limited in phenylalanine, and to assess critically the mental progress attained in a group of six children treated for up to three years with such diets.

\section{Dietary Control}

The preliminary studies in one child (Sheila) were reported by Bickel et al. in 1953; this child has since remained at home on the diet with frequent hospital visits. More accurate control of the diet has been achieved in the Metabolic Research Unit for long periods in two children, Michael and Robin. In these children weight was measured daily and frequent determinations of plasma and urine phenylalanine were carried out by microbiological assay (Henderson and Snell, 1948). The urine and stools were collected over 24 to 48 -hour periods on a specially designed metabolic bed (Blainey, 1956). These specimens were analysed for total nitrogen by the micro-Kjeldahl method and the nitrogen intake was checked by digestion and Kjeldahl analysis of diets. Urine creatinine was determined as a rough check on the completeness of the collections of urine.

The dietary intake was unchanged throughout apart from variations designed to observe the effect of changes in calory, carbohydrate and phenylalanine intakes. The main source of nitrogen in the diet has been a casein hydrolysate low in phenylalanine, ${ }^{*}$ from which tyrosine, cystine and tryptophane have also been largely removed during manufacture. The casein has been given in a blancmange of the following composition:

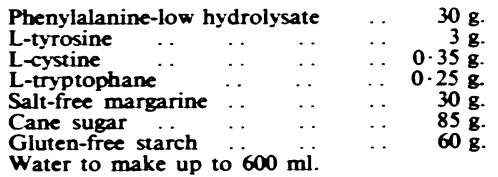

This quantity was given to the in-patients daily, in three feeds, the starch and sugar helping to disguise the bitter taste of the hydrolysate. In addition, they received orange juice with $30 \mathrm{~g}$. sugar at $10 \mathrm{a} . \mathrm{m}$. and $100 \mathrm{~g}$. of mashed vegetables (excluding potatoes, owing to their high protein content) with $15 \mathrm{~g}$. fat, and $100 \mathrm{~g}$. apple, banana or other fruit purée with sugar was given at lunch time. A mineral mixture, containing essential vitamins was given in the main feeds, similar to that used by Woolf et al. (1955). The same diet was advised for the out-patients, the amount of casein hydrolysate and carbohydrate being varied to give equivalent amounts per kg. body weight for each child. The children were weighed and examined monthly when blood was drawn for haemoglobin and phenylalanine estimations. A

- Manufactured by Allen and Hanbury, Ltd., Ware. In addition. a daily supplement containing phenylalanine, usually in the form of milk, was given as indicated in each case report helow. 
sample of urine was tested with ferric chloride for phenylpyruvic acid and by paper chromatography for phenylalanine and other amino-acids. The urine was also examined for tryptophane derivatives by a modification (Leyton, 1956) of the method of Dalgliesh (1955).

\section{Mental Testing}

All the testing was carried out by one of us (R.G.). Several tests have been required in order to cover the range of mental ability from 5 months to 6 years. One child has been tested annually on the new revised Stanford-Binet scale (Terman and Merrill, 1937). The main difficulty has been the comparable measurement of mental ages below 2 years. The Griffiths method of testing the abilities of babies (1954) is the most satisfactory for this purpose, but was not available until much of this work was completed. Assessments were also made with the Buehler tests (Buehler and Hetzer, 1935), with Gesell's developmental schedules (Gesell and Amatruda, 1941) and with the Vineland social maturity scale (Doll, 1935).

The Buehler tests were found useful since the test materials, e.g., bells, rattles, tops, etc., are attractive to mentally retarded children, but the system has several drawbacks, notably the lack of speech items, and tends to over-estimate development in this type of case. The Gesell developmental schedules are valuable for observation and assessment of progress, but have the disadvantage that the results are not easily expressed in mental ages and quotients. The Griffiths scale has a greater variety of attractive test material and has been well standardized on normal English children below 2 years of age. It affords a profile of development with five subscales (locomotor, personal-social, speech and hearing, eye and hand, performance). Mental ages and quotients are obtained for each subscale separately and also for the full scale. Testing at intervals, the gain in mental age for that period can be expressed as a progress rate equal to

$$
\frac{\text { Gain in weeks of mental age } \times 100}{\text { No. of weeks between tests }}
$$

Since 1955, the Griffiths scales have been used for the three-monthly assessment of mental ages of the children on diets and a roughly comparable figure for mental ages between times and in different patients has thus been obtained. A cine-film record has been made of the progress in Michael which has been most valuable in recording progress in aspects of behaviour that are difficult to test formally.

\section{Case Reports}

Case 1. Michael, born on March 31, 1952, the first child of healthy parents, was regarded as normal until 12 months, when feeding became difficult and he would not sit up. At 18 months he was referred to hospital with feeding difficulties and attacks of screaming, limb stiffness and loss of consciousness. The child was reported as backward and no specific diagnosis was made. As these attacks were still present six months later and feeding was increasingly difficult, he was admitted to Chelmsley Hospital, Birmingham, as a certified mental defective. The diagnosis of phenylketonuria was established, and after a short period of re-feeding, he was transferred to the Metabolic Unit, Little Bromwich Hospital, on December 7, 1954. He was fair haired, considerably underweight and behaved like an infant of 6 months. He seemed happy, responded with smiles to visitors, and lay much of the time rubbing his hands or face in repetitive mannerisms. He could not sit up unaided; when placed prone, he was quite helpless and made no crawling movements. On examination, his teeth were abnormal. grey, and ground down almost to the alveolar margin (Fig. 1). The leg muscles were poorly developed but

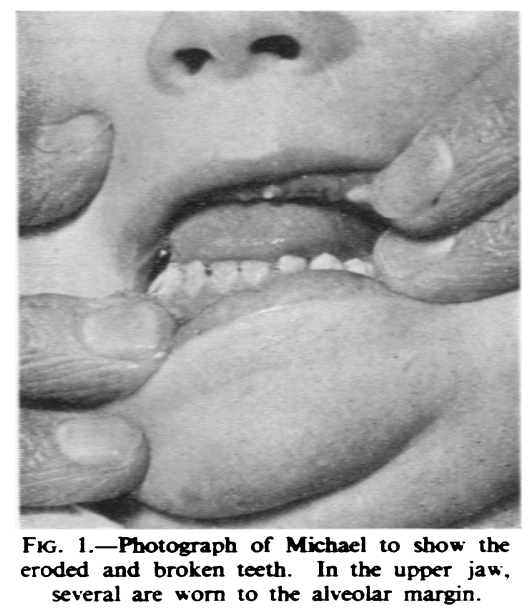

he seemed otherwise normal. Phenylpyruvic acid was present in large amounts in the urine, the daily phenylalanine output was greatly raised, and plasma phenylalanine was $42 \mathrm{mg}$./ $100 \mathrm{ml}$. (Fig. 2). Haemoglobin was 11.6 g. $/ 100 \mathrm{ml}$., r.b.c. $4,300,000 /$ c.mm.: p.c.v. $36^{\circ}{ }_{0}$ : m.c.v. $82 \mathrm{cu} . \mu$ : plasma proteins $7.0 \mathrm{~g} . / 100 \mathrm{ml}$., with a normal electrophoretic pattern. Radiographs of the skull and wrists showed no abnormality, with a bone age consistent with chronological age (Acheson, Kemp and Parfit, 1955).

Shortly after admission he developed bronchopneumonia, which was successfully treated with penicillin. He also developed a mild dysentery due to Giardia lamblia and Shigella sonnei infection which responded to treatment. During the following four weeks on normal diet he gained $2.3 \mathrm{~kg}$. in weight, and was in positive nitrogen balance (Fig. 2). Urine phenylalanine and phenylpyruvic acid remained unaltered; there was a mild generalized amino-acidura and excess tryptophane derivatives were found on paper chromatography (Table 1). Phenylalanine restriction was started on January 23, 1955, at first without a milk supplement, when the weight fell. One hundred millilitres of milk daily was insufficient to permit gain in weight, so the amount was increased to $150 \mathrm{ml}$. per day (total phenylalanine intake $250-270 \mathrm{mg}$. day). Blood and urine chemistry reverted rapidly to normal on this diet, and remained normal, with a considerably greater gain in weight than expected for his age during the next three months. 
TABLE 1

EXCRETION OF URINARY AROMATIC COMPOUNDS (PAPER CHROMATOGRAPHY) IN MICHAEL

\begin{tabular}{|c|c|c|c|c|c|c|c|c|}
\hline & & 3.1 .55 & 1.3 .55 & 15.3 .55 & 3.6 .55 & 29.10 .55 & 27.11 .55 & 10.1 .56 \\
\hline 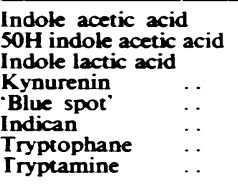 & $\begin{array}{l}\cdots \\
\cdots \\
\cdots \\
\cdots \\
\cdots \\
\cdots \\
\cdots\end{array}$ & $\begin{array}{c}-- \\
-- \\
- \\
- \\
- \\
-\end{array}$ & $\begin{array}{c}-- \\
\overline{-} \\
\overline{-} \\
\overline{-} \\
-\end{array}$ & $\begin{array}{c}-\overline{-} \\
-\overline{-} \\
\overline{-} \\
\overline{-} \\
\overline{\text { Trace }}\end{array}$ & $\begin{array}{c}\overline{-} \\
\text { Trace } \\
- \\
- \\
-- \\
-\end{array}$ & $\begin{array}{l}\overline{-} \\
\text { Trace } \\
\overline{-} \\
\overline{-} \\
\overline{-}\end{array}$ & $\begin{array}{c}\overline{-} \\
\overline{-} \\
\overline{-} \\
\overline{-} \\
\overline{-} \\
\text { Trace }\end{array}$ & $\begin{array}{c}+- \\
\dot{-} \\
\text { Trace } \\
- \\
\text { Trace } \\
-\end{array}$ \\
\hline $\begin{array}{l}\text { Phenylalanine } \\
\text { Phenylpyruvic acid }\end{array}$ & $\begin{array}{l}\ldots \\
\cdots\end{array}$ & $\ldots-$ & - & - & Trace & - & - & - \\
\hline
\end{tabular}

TABLE 2

NITROGEN EXCRETION AND BALANCE IN MICHAEL

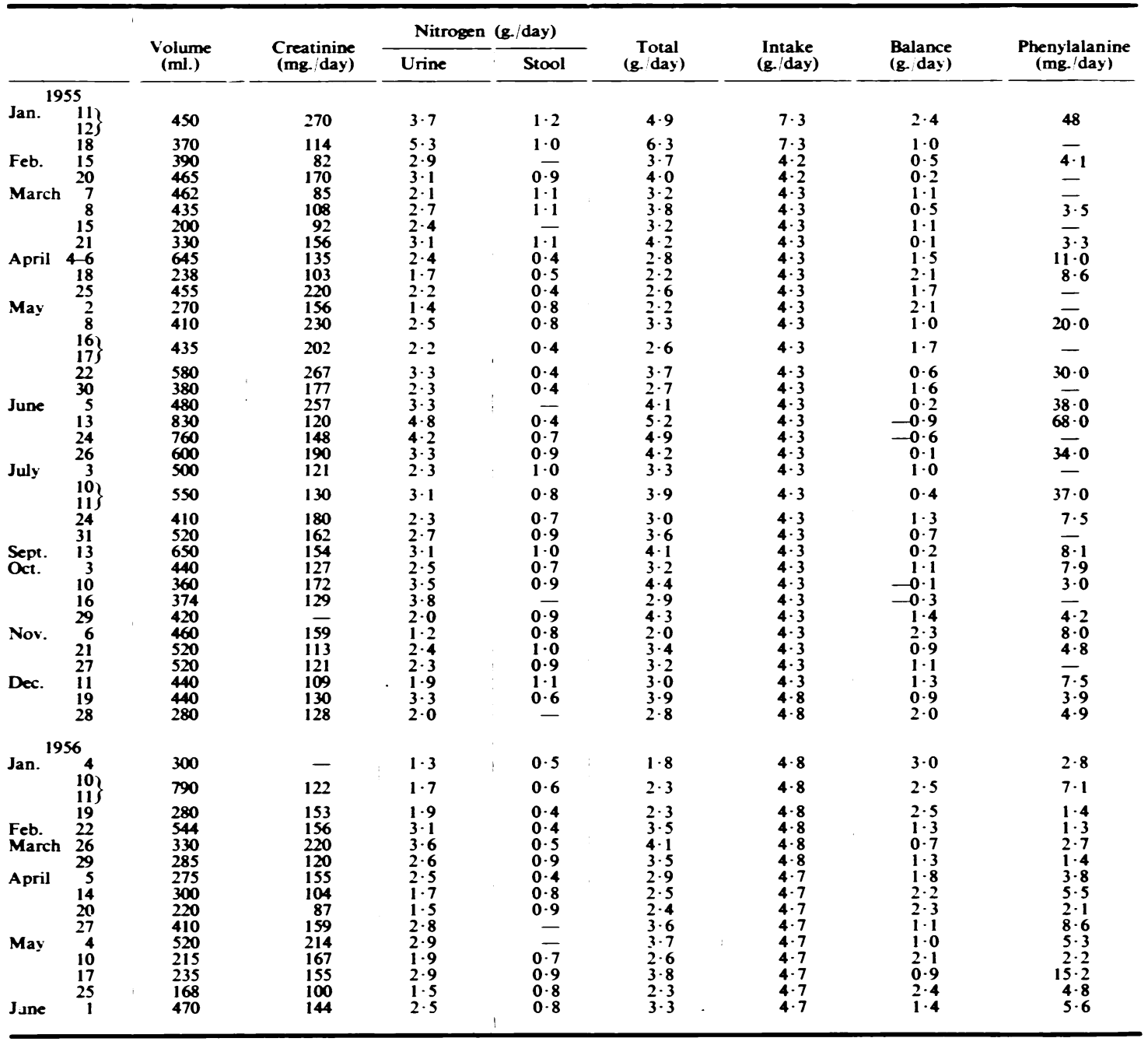


The intake of 1,440 calories per day was then reduced to $1,220 \mathrm{cal}$./day by reduction of cane sugar, as it was thought that fat gain was excessive. About a week later the child was quieter, less active and responsive, and realized, although weight loss suggested an inadequate calory intake. The latter was therefore increased to the previous level, with a rapid return of the plasma and urine chemistry to normal, and with an increase in the child's interest in his surroundings. This effect of calory restriction was again observed when the diet was held constant with rising body weight. When the intake became equivalent to $95 \mathrm{cal} . / \mathrm{kg}$./day, the biochemical abnormalities again appeared. On the third occasion, the calory intake was reduced by a decrease in the fat intake, and on this occasion neither physical nor mental slowing nor biochemical abnormality was observed although the weight remained stationary. The diet was then returned to a level of 110 cal./kg./day, with high carbohydrate intake. The detailed nitrogen balance figures are given in Table 2. During the whole period the child gained weight and height at normal or increased rates (Fig. 5). Haemoglobin concentration, initially low, rose to normal levels after four months' treatment and remained at a normal value throughout the 15 months.

mental Changes. These are shown in Table 3.

January 17, 1955. After one month in hospital on normal diet. Chrono-

formal testing suggested that the rapid improvement of the first few months was slowing. The plasma and urine phenylalanine increased, but except at the highest peaks of phenylalanine excretion, the urine was free from phenylpyruvic acid. The nitrogen balance became negative for the first time, and the weight fell slightly. The significance of these changes was not immediately logical age (C.A.) 2 years 10 months. Mental age (M.A.) 5 months.

Michael was unable to sit unaided, and lay kicking or gazing at his hands, which he constantly rubbed together, turning his head towards anyone approaching and smiling. Placed in the prone position, he lay helpless and howled, making neither righting nor crawling movements.

TABLE 3

RESULTS OF MENTAL TESTING ON GRIFFITHS SCALE IN MICHAEL

\begin{tabular}{|c|c|c|c|c|c|c|c|c|c|c|c|c|}
\hline Date & \multicolumn{2}{|c|}{17.1 .55} & \multicolumn{2}{|c|}{ 19.4.55 } & \multicolumn{2}{|c|}{22.7 .55} & \multicolumn{2}{|c|}{21.10 .55} & \multicolumn{2}{|c|}{17.1 .56} & \multicolumn{2}{|c|}{17.4 .56} \\
\hline $\begin{array}{l}\text { Chrono- } \\
\text { logical age } \\
\text { (weeks) } . .\end{array}$ & \multicolumn{2}{|c|}{145} & \multicolumn{2}{|c|}{158} & \multicolumn{2}{|c|}{172} & \multicolumn{2}{|c|}{185} & \multicolumn{2}{|c|}{198} & \multicolumn{2}{|c|}{211} \\
\hline $\begin{array}{l}\text { Mental Age } \\
\text { (weeks) }\end{array}$ & $\begin{array}{c}\text { Mental } \\
\text { Age }\end{array}$ & Quotient & $\begin{array}{c}\text { Mental } \\
\text { Age }\end{array}$ & Quotient & $\begin{array}{c}\text { Mental } \\
\text { Age }\end{array}$ & Quotient & $\begin{array}{c}\text { Mental } \\
\text { Age }\end{array}$ & Quotient & $\begin{array}{c}\text { Mental } \\
\text { Age }\end{array}$ & Quotient & $\begin{array}{c}\text { Mental } \\
\text { Age }\end{array}$ & Quotient \\
\hline $\begin{array}{r}\text { Scale A } \\
\mathbf{B} \\
\mathbf{C} \\
\mathbf{D} \\
\mathbf{E}\end{array}$ & $\begin{array}{l}18 \\
23 \\
25 \\
23 \\
23\end{array}$ & $\begin{array}{l}13 \\
16 \\
17 \\
16 \\
16\end{array}$ & $\begin{array}{l}40 \\
26 \\
28 \\
28 \\
30\end{array}$ & $\begin{array}{l}25 \\
17 \\
18 \\
18 \\
19\end{array}$ & $\begin{array}{l}45 \\
40 \\
28 \\
31 \\
35\end{array}$ & $\begin{array}{l}26 \\
23 \\
16 \\
18 \\
20\end{array}$ & $\begin{array}{l}51 \\
41 \\
38 \\
43 \\
40\end{array}$ & $\begin{array}{l}27 \\
22 \\
20 \\
23 \\
21\end{array}$ & $\begin{array}{l}56 \\
49 \\
46 \\
46 \\
41\end{array}$ & $\begin{array}{l}29 \\
25 \\
24 \\
24 \\
21\end{array}$ & $\begin{array}{l}61 \\
54 \\
52 \\
50 \\
41\end{array}$ & $\begin{array}{l}29 \\
26 \\
25 \\
24 \\
20\end{array}$ \\
\hline Full scale & 22 & 15 & 30 & 19 & 36 & 21 & 43 & 23 & 48 & 24 & 52 & 25 \\
\hline $\begin{array}{l}\text { Progress } \\
\text { Rate }\end{array}$ & & & & 66 & & 43 & & 54 & & 39 & & 33 \\
\hline
\end{tabular}


He could not support his weight in the standing position. He reached for objects when lying, but not when sitting, and his attention was very limited.

April 19, 1955. (C.A. 3 years 1 month, M.A. 7 months.) After three months on a restricted diet, he could sit without support, pivoted around in a sitting position, took his weight when held standing and made stepping movements. When placed prone, he made swimming movements with his legs. He manipulated test objects with greater skill, but could manage only one at a time. He showed increased awareness of his surroundings and enjoyed a frolic with Sister. He would look for keys, etc., held and then concealed by the examiner. The habitual movements were less conspicuous and his response to personal attention was more varied.

July 22, 1955 (C.A. 3 years 4 months, M.A. 8 months). During this three months, less improvement had occurred, possibly as a result of the biochemical abnormality caused by carbohydrate restriction. He could stand when grasping a rail, but could not lift himself up. In the prone position he could reach for things, but not crawl. He responded well to people and showed marked affection for the ward sister. The introduction of another child into his room for the first time caused obvious reactions of jealousy, Michael demanding attention in a way that had not previously been observed. He made a greater variety of noises but little real progress in speech sounds was recorded. He was more active with toys, lifted a cup to seek toys placed beneath it, crumpled paper, and picked up and rattled small boxes.

October 21, 1955 (C.A. 3 years 7 months, M.A. $9 \cdot 5$ months). Biochemical control was again satisfactory and progress rate returned to that of the first three months. This was most marked in locomotion, as he could pull himself up to stand by a chair, walk with support and move around in a sitting position. Looking in a mirror produced genuine chuckles; he was more socially responsive and would join in games of "pat-acake'. He also cooperated in simple ways of dressing and experimented with new sounds although no words were recognizable. In manipulation, he had reached the stage of picking things up and throwing them, and had begun to use finger and thumb more skilfully.

February 1, 1956 (C.A. 3 years 11 months, M.A. 11 months). After 12 months $^{\circ}$ treatment the most striking change was again in locomotion as he had learned to walk unaided. Other aspects were now difficult to test, and few new abilities had emerged, although those observed fleetingly in October seemed to have become established. He was at approximately an 11-monthstage of development. but did not always seem to be aware of being spoken to, did not react to strangers as such, and his interest in play articles was confined to throwing them about.

April 17, 1956 (C.A. 4 years 1 month, M.A. 12 months). Walking was more certain, he began to climb stairs, and would look briefly at pictures. Testing was again difficult as he continually cast toys, etc., on the floor and his attention could not be secured for long. Two months later, however, he was again showing progress, since he was responding in bladder and bowel control, and walking was fully established.

On admission to hospital, Michael was below 6 months in mental age. He could neither sit nor crawl; he could grasp at rings held in his line of vision and within his reach. In the following 14 months, he learned to sit up, to stand, to walk, to respond with affection to people around him, to respond to toilet training and to make some progress in speech sounds.

Case 2. Sheila, born on October 1, 1949, was first admitted to the Children's Hospital, Birmingham, under the care of Professor Smellie, on September 25, 1951. She was the third child of normal, unrelated parents, and had been normal at birth. She sat up at 9 months, but was thought to be backward. On admission (age 2) she was unable to sit for long, could stand with support and could neither walk nor talk. There were frequent head banging movements. She was well nourished and showed no abnormal physical signs. The typical biochemical features of phenylketonuria were present (Fig. 3). She was first treated on a phenylalanine-free diet, and later on a restricted intake, with marked improvement especially in awareness and in motor activity. These changes were reported in detail by Bickel et al. (1953). The phenylalanine restriction was started in December, 1951, and apart from two short periods in hospital was continued at home until November, 1955, although control was not always satisfactory. Plasma levels of phenylalanine were consistently above normal values, and the urine contained excess phenylalanine although it was generally free from phenylpyruvic acid.

In April, 1955, a fourth child was born and the dietary control became worse at home, plasma and urine phenylalanine levels rose and the ferric chloride test became positive. In this period there was a considerable gain in weight, which had been stationary for much of 1953-55, in spite of what was then regarded as an adequate calory and carbohydrate diet. In view of the difficulties of satisfactory maintenance, the diet was relaxed to a limited protein intake in December, 1955.

Mental Changes. Development was not assessed when treatment was first started in December, 1951. From May, 1953, assessments were made using different techniques (Table 4) and showed considerable variation due to differences in the rates of development of various aspects tested. There was a gain in many features (except speech) in the first year of testing. The following description shows the main trends:

May, 1953 (C.A. 3 years, 7 months, M.A. 10 months). After 17 months of restricted phenylalanine intake, Sheila could not stand without the aid of furniture. She would climb on to a chair, crawl actively and explore cupboards and objects at floor level. She was indifferent to toys unless they made a noise or moved, e.g., ball or top. She would not hold two objects at once. The thumb was beginning to be used in manipulation. She made some two-syllable babble and kissing noises. Her attention span was limited and she quickly tired, cried and lay rocking on the floor. 
TABLE 4

RESULTS OF MENTAL TESTING IN SHEILA

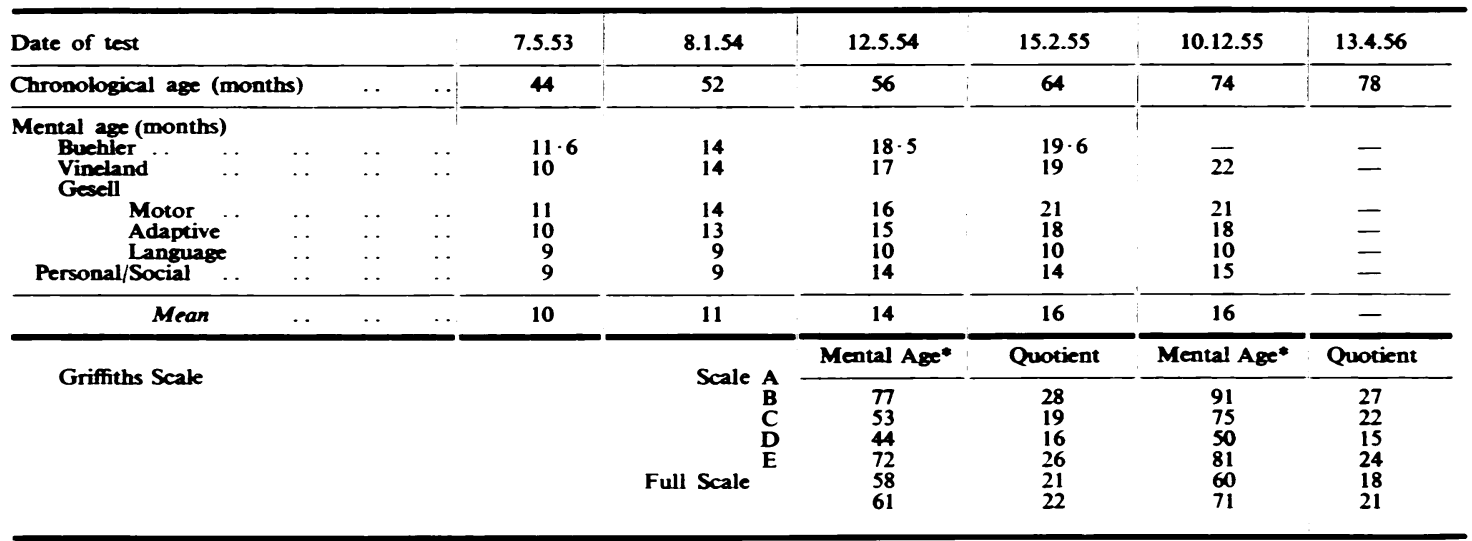

- Griffiths scale ages in weeks.

January, 1954 (C.A. 4 years 3 months, M.A. 12 months). After two years of treatment she was able to stand and would walk a few steps with help. Attention span was markedly increased, and she was interested in more objects. Thumb opposition was complete: she could pick up a pellet neatly and place one brick on another. She made a stroke with a pencil and looked briefly at a picture book. Apart from language, she was at about the 12-month level.

May, 1954 (C.A. 4 years 7 months.) This was 12 months after the first assessment, and two years five months after the start of treatment. She was now walking alone, and could seat herself in a small chair or climb into a child's push-along wagon. She was

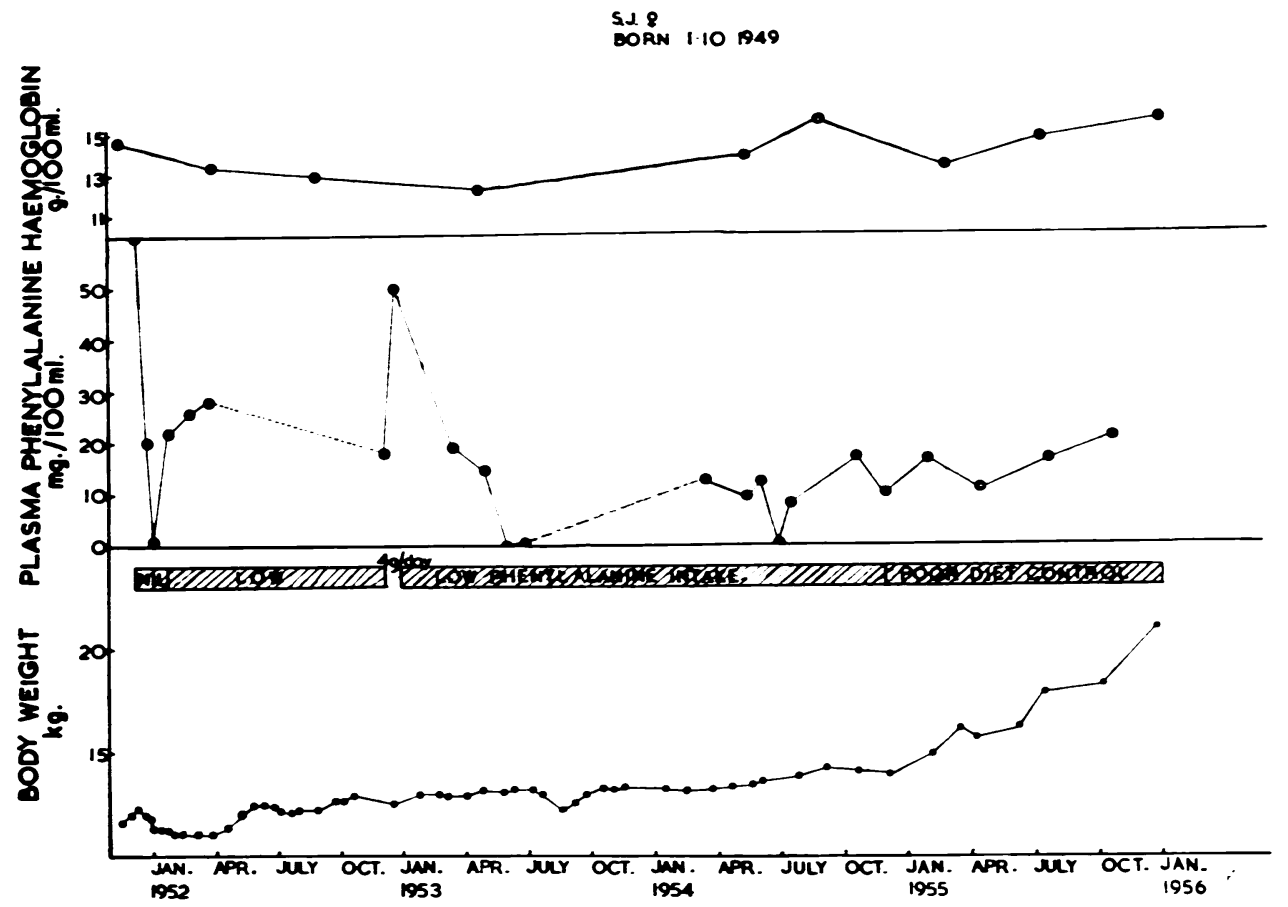

Fig. 3.- Chart showing dietary and biochemical changes in Sheila. Steep rise in weight after January, 1955, due to increased calory intake above increased protein. 
considerably more interested in playing with toys - thus she tried to spin a top by pumping the handle and to build a tower with cubes. She would fill a cup with cubes, scribble with a pencil and look at a picture book. In motor development she was rated at 18 months and in other aspects at $\mathbf{1 5}$ months, apart from speech which had still not advanced beyond the 12-month stage. In the 12 months she had gained five months of mental development, a progress rate of $40 \%$.

February, 1955 (C.A. 5 years 4 months). Locomotion had further improved, as she could walk kicking a ball and could squat in play. She made a tower of bricks, scribbled with a pencil and liked carrying a doll. She placed a round block in a form-board, drank from a cup and pointed to indicate her needs; language continued to lag. Progress in this period had continued, but at a slower rate than in the preceding 12 months. The considerable variation of different aspects of development is indicated by the results of the first testing on the Griffiths scale at this time (Table 4).

December, 1955 (C.A. 6 years 2 months). After two years of treatment, the deterioration in home circumstances and dietary control was reflected in her manner. She was more easily distracted and test materials were almost invariably thrown on the floor. Nevertheless, some progress was recorded, she could use a cup and spoon by herself, could take the paper off a sweet and walked along pulling a toy.

April, 1956 (C.A. 6 years 6 months, M.A. 1 year 6 months). After Sheila had been five months on a low-protein diet, her mother claimed that she was well, and was continuing to acquire new activities at home. She was, however, uncooperative and distractable during

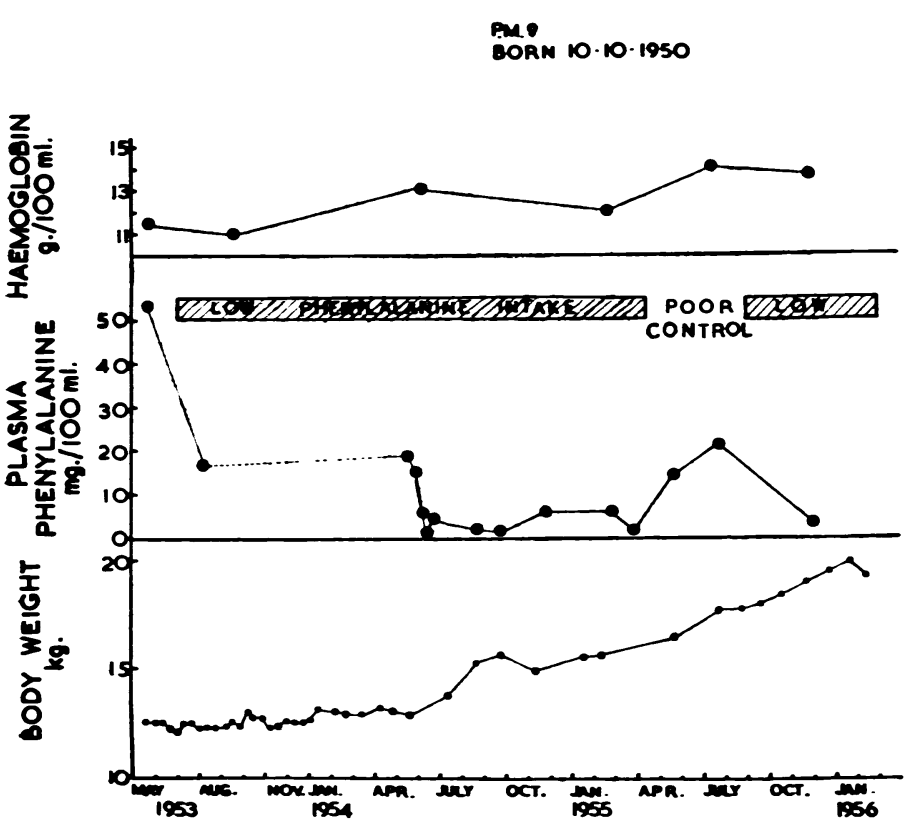

Fig. 4.-Chart showing dietary and biochemical changes in Pauline. testing and although mental tests showed continued improvement, it was clearly at a considerably lower rate than previously (Table 4).

Case 3. Pauline, born on October 10, 1950, was first admitted to the Children's Hospital, Birmingham, under the care of Dr. J. Gerrard in July, 1953; she was the second child of healthy parents. The other child was normal, and Pauline had been regarded as normal until about 1 year old. She had sat up at 9 months and walked at 18 months, but made no attempt to talk or to feed herself. She had suffered from attacks from the age of $\mathbf{1 0}$ months when she fell in her cot and rolled her eyes; these attacks were said to be getting more frequent. On admission, she appeared physically normal for her age and there were no abnormal signs. The teeth were rather widely spaced but not ground down. Plasma phenylalanine was raised with excessive excretion in the urine; which also contained phenylpyruvic acid. The child was placed on a phenylalanine-free diet by Dr. Bickel for two weeks and then given $200 \mathrm{mg}$. daily of L-phenylalanine, but no milk. The urine was free from phenylpyruvic acid on this amount. She was later discharged from hospital on the diet similar to the other children, with $75 \mathrm{~g}$. milk instead of the phenylalanine.

She remained well at home on this régime for some weeks and gained weight; the urine was free from phenylalanine on paper chromatography, and the ferric chloride reaction was negative. The dietary control deteriorated and she was readmitted on May 15, 1954, when the biochemistry was again restored to normal by strict diet. She was transferred to St. Margaret's Hospital, Birmingham, where the diet was strictly enforced for the following 12 months. The plasma phenylalanine remained only slightly raised above normal levels and the urine was free from phenylpyruvic acid (Fig. 4). In May, 1955, there was a rise in the plasma phenylalanine traced to the accidental addition of protein to the diet. The calory intake of this child was kept high (100-110 cal./kg./day) with glucose and sweetened drinks, in addition to the basic amounts in the casein mixture. For a time this was given as a drink as the child objected to it in any other form, but it was later found to be more satisfactory in the blancmange already described. The diet was finally changed to a low-protein intake in December, 1955, in view of the slight mental improvement after 18 months' satisfactory dietary control.

Mental Changes. These are set out in Table 5.

September, 1953 (C.A. 2 years 11 months). Before treatment assessment on the Buehler scale gave a mental age of 8 months, and the Vineland scale of $8 \cdot 8$ months. She could sit up without support, walked a few steps with aid 
TABLE 5

RESULTS OF MENTAL TESTING IN PAULINE

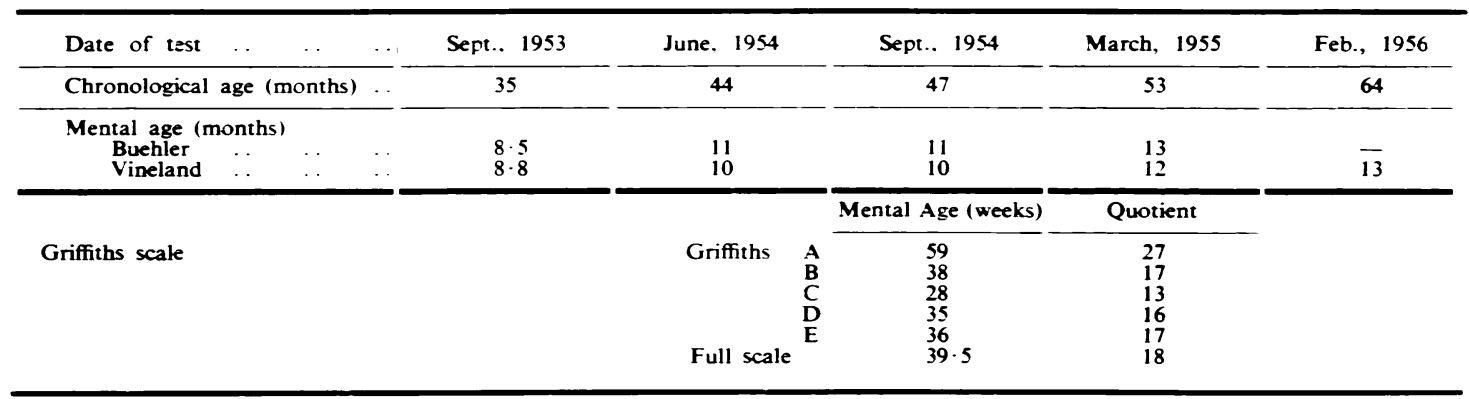

and stood with the aid of a chair. She made a few sounds but showed little awareness of people. She grasped at objects, waved a bell, rattled a box of cubes but could not manipulate two objects at once. She rocked frequently, ground her teeth and often broke into loud cries.

June, 1954. She had now learned to stand alone and could walk, though unsteadily. She could hold two objects simultaneously and could pull a string to obtain a toy. The Buehler scale gave a development age of 11 months, items relating to locomotion providing most of the improvements.

September, 1954. Locomotion was greatly improved and she ran about vigorously. The crying and teeth grinding had diminished, but she remained unresponsive to people or to her environment.

January, 1955 (C.A. 4 years 3 months). Locomotion again showed progress to above the one-year level. She could run, walk backwards, and climb into a chair. She showed some improvement in social relationships, at times seeking and showing affection, although she was uncooperative in dressing or feeding. There was no progress in speech. It was difficult to test her manipulation of objects, as she tended to finger things rather than to grasp them, and put them finally in her mouth. Testing for the first time on the Griffiths scale showed a mental age of 40 weeks, with a quotient of 18 (Table 5).

March, 1955. An estimate with the Buehler scale placed her at 13 months, with locomotion still contributing much of the improvement. She preferred running aimlessly around the room to playing with test materials and would not build with cubes or put things into a cup. She would grasp at a string, but merely put it into her mouth and did not attempt to play with the toy attached. She preferred to bang objects against the table or to put them in her mouth and there did not seem to be much change in her handling of materials.

January, 1956. A further attempt was made to test with the Griffiths scale, but she was quite unresponsive to the test materials. If she handled toys they were immediately put into her mouth. She ran about the room constantly and had a habit of sucking at hard objects at head height. She seemed curiously withdrawn, paying little attention to her surroundings and unresponsive to the nurses caring for her.
Case 4. Malcolm, born on May 13, 1949, was first admitted to the Children's Hospital under the care of Dr. J. Gerrard in January, 1954. He was the first child of healthy parents, who were second cousins. He was normal at birth but started to have convulsions at the age of 6 months, which had continued about twice monthly until admission. The attacks were all similar, with clonic spasms of the hands and legs and convergent movements of the eyes which lasted for a few seconds. He sucked normally, took solid food at 9 months, but at 5 years was unable to stand, feed himself or talk. He was difficult to examine, crying readily on any interference. The teeth were ground down and widely spaced: the heart, lungs and abdomen appeared normal and there were no abnormal signs in the upper limbs. The lower limbs were hypotonic, and the reflexes impossible to test. The urine contained excess phenylalanine, and there was a strongly positive ferric chloride reaction.

On a phenylalanine-free diet he lost weight, and vomited. so $150 \mathrm{ml}$. milk was added daily but as phenylpyruvic acid reappeared in the urine the milk was reduced to $100 \mathrm{ml}$. The addition of $5 \mathrm{~g}$. phenylalanine to his diet caused marked deterioration, the child becoming weak and miserable and making little attempt to move. Similar findings were seen in Sheila on large doses of phenylalanine (Bickel et al., 1955). A strict diet, with limitation of phenylalanine to $250 \mathrm{mg}$./day, was then started and he appeared more active. In May, 1954, he developed status epilepticus, lasting for 48 hours. He improved, and was later discharged on the same diet, and seen regularly in the Out-patient Department. The plasma phenylalanine remained raised above normal levels, and it was thought that he must be receiving additional protein. He was readmitted to the Metabolic Ward for assessment on June 1, 1955. The fits were still occurring regularly but were mainly of petit mal type and were unaffected by phenobarbitone or phenytoinum sodium ('epanutin'). The legs were still hypotonic and he was unable to walk. The plasma phenylalanine level was $5.3 \mathrm{mg}$. $/ 100 \mathrm{ml}$.; with proper diet restriction it fell to $1.9 \mathrm{mg} . / 100 \mathrm{ml}$. and the excretion in the urine fell to $2.5 \mathrm{mg}$. per day. Further fits, several of major type, occurred in hospital and in view of the very limited improvement which had been 
obtained he was discharged on a low-protein intake in July. His condition has remained unchanged.

Mental State. The findings are set out in Table 6. January, 1954 (C.A. 4 years 8 months). The development age on the Buehler scale was assessed at about five months. He was unable to sit up unaided, and lay flat in his cot with his legs in the air playing with his toes. When held up, he made no attempt to take his weight or to make stepping movements. He was able to hold a rattle, to bang toys against a table and to appreciate sound. There was little response to people, and he made no articulate sounds.

He was seen at intervals throughout the year of phenylalanine restriction but no formal testing was carried out. In January, 1955, assessment on the Buehler scale gave a mental age of 7 months; on the Griffiths scale he scored at 27 weeks, with a quotient of 9. The main change in the year was the development of a firm sitting posture and greater activity with toys. There was no attempt at speech and he would not stand. Six months later there again appeared to be no change in his condition.

TABLE 6

RESLLTS OF MENTAL TESTING IN MALCOLM

\begin{tabular}{|c|c|c|c|}
\hline Date of test & Jan., 1954 & Jan.. 1955 & July. 1955 \\
\hline $\begin{array}{c}\text { Chronological age } \\
\text { (months) }\end{array}$ & 56 & $\begin{array}{c}68 \\
\text { (294 weeks) }\end{array}$ & 74 \\
\hline $\begin{array}{l}\text { Mental age (months) } \\
\text { Buehler }\end{array}$ & 5 & 7 & 7 \\
\hline G-iff the cole & Mental Age & Quotient & \\
\hline $\begin{array}{r}\text { Griffiths } \underset{\text { A }}{\text { A }} \\
\text { Full siale } \\
\text { D } \\
\text { E }\end{array}$ & $\begin{array}{l}23 \\
29 \\
17 \\
26 \\
29 \\
27\end{array}$ & $\begin{array}{r}8 \\
10 \\
6 \\
9 \\
10 \\
9\end{array}$ & \\
\hline
\end{tabular}

Case 5. Sylvia, born on January 21, 1945, was admitted to the Children's Hospital under the care of Dr. J. Gerrard to assess the effect of phenylalanine restriction on an older and severely affected child. She had been in St. Margaret's Hospital since the age of 6 . She sat up late and had not walked until the age of 3 . She was withdrawn, wild and quite uninterested in her surroundings, frequently banging her head and boxing her own ears. Her hair was dark unlike all the other children, and her teeth widely spaced, though not ground down. The reflexes were brisk, but muscle tone was normal. She was impossible to test by any formal method, so that no definite mental age could be obtained. The plasma phenylalanine was $24.5 \mathrm{mg}$. $100 \mathrm{ml}$. on admission, and the urine phenylpyruvic acid averaged $350 \mathrm{mg}$. 24 hours (Penrose and Quastrel, 1937). Phenylalanine restriction started on May 27, 1953, and she became more docile, easier to manage and showed more interest in activities around her. The plasma phenylalanine fell to normal values. The diet, which was continued for two years, consisted of $50 \mathrm{~g}$. of the casein hydrolysate together with amino-acid mixtures as given to the other children. She received a calory intake of 1,400 per day, with approximately $300 \mathrm{mg}$. phenylalanine. On this régime the plasma phenylalanine was above normal, but the urine was free from phenylpyruvic acid.

After 18 months of dietary restriction, her behaviour seemed less negative. She still banged her head, though less often, and had on occasions showed interest in test materials, although her attention was not sustained. She was very active, with numerous bizarre jerking movements of the limbs and trunk. The Vineland scale placed her at 12 months. While there had been definite personality changes on the diet, there was no measurable intellectual advance.

In June, 1956, after seven months of ncrmal diet, her condition had reverted to that seen before treatment. She was completely withdrawn and unresponsive to any approach, except to that of another high-grade patient. She had on occasion refused all food except that given by this girl. She crouched on the floor, hiding her head in her arms, frequently banging her head and making loud grunting noises.

Case 6. Robin, born on May 12, 1954, is the brother of Malcolm. He was born in hospital and the urine was examined by Dr. Bickel two weeks after birth when phenylalanine loss was normal and no phenylpyruvic acid was present. He grew normally and was regarded as normal by his parents. At 8 months he developed fever and ascites, with a positive Mantoux reaction. A diagnosis of tuberculous peritonitis was made, and on admission to hospital at Worcester it was noticed that the urine gave a positive reaction for phenylpyruvic acid. He was transferred to the Children's Hospital, Birmingham, under Dr. O. Wolff and treated with a normal diet, streptomycin and isonicotinic-acid hydrazine, with satisfactory resolution of the ascites and fever. The plasma phenylalanine was $38.5 \mathrm{mg}$. $/ 100 \mathrm{ml}$. and the daily urinary excretion $270 \mathrm{mg}$. After three months treatment, he was admitted to the Metabolic Unit for further study of the phenylketonuria. He was an attractive, fair-haired, blue-eyed child with a bright, alert face and was friendly towards visitors. He could sit up easily, and pull himself to a standing position. He crawled readily and actively and appeared purposeful in his movements. There were no abnormal physical signs (Hb 11 g./100 ml., E.S.R. $1 \mathrm{~mm}$. hr.). After a short period on normal diet, the phenylalanine intake was limited to $250 \mathrm{mg}$./day, with 1,200 calories day. The plasma and urine phenylalanine became normal within a few days. Before treatment, there was a gross excess of indole lactic acid, indole acetic acid and tryptamine in the urine which disappeared after restriction of phenylalanine. He remained in positive nitrogen balance and gained weight after a further three months on the diet in hospital (Table 7) when he was discharged home. The parents were unzonvinced that there was any mental abnormality (in relation to Malcolm, their other child, this view was understandable) and were reluctant to continue with any dietary restriction. Robin was therefore given a highcalory, low-protein intake, calculated to give 500-600 mg. phenylalanine per day. He has been seen regularly in 
TABLE 7

NITROGEN BALANCE IN ROBIN

\begin{tabular}{|c|c|c|c|c|c|c|c|c|c|}
\hline & & $\begin{array}{l}\text { Volume } \\
\text { (ml.) }\end{array}$ & $\begin{array}{r}\text { Creatinine } \\
\text { (mg. day) }\end{array}$ & $\begin{array}{c}\text { Urine } \\
\text { Nitrogen } \\
\text { (g. day) }\end{array}$ & $\begin{array}{l}\text { Stool } \\
\text { Nitrogen } \\
\text { (g. day) }\end{array}$ & $\begin{array}{l}\text { Total } \\
\text { (g. daỹ) }\end{array}$ & Intake & Balance & $\begin{array}{c}\text { Urine } \\
\text { Phenylalanine } \\
\text { (mg. day) }\end{array}$ \\
\hline $\begin{array}{r}3.10 .55 \\
9.10 .55 \\
17.10 .55 \\
19.10 .55 \\
4.11 .55 \\
15.11 .55 \\
23.11 .55 \\
30.11 .55 \\
8.12 .55\end{array}$ & $\begin{array}{l}\cdots \\
\cdots \\
. \\
. \\
. \\
\cdots \\
.\end{array}$ & $\begin{array}{l}285 \\
275 \\
300 \\
224 \\
350 \\
290 \\
620 \\
450 \\
436\end{array}$ & $\begin{array}{r}95 \\
102 \\
130 \\
100 \\
- \\
1 \overline{139} \\
125 \\
110\end{array}$ & $\begin{array}{l}2 \cdot 7 \\
2 \cdot 6 \\
2 \cdot 3 \\
4 \cdot 5 \\
2 \cdot 9 \\
3 \cdot 9 \\
2 \cdot 9 \\
3 \cdot 9 \\
2 \cdot 2\end{array}$ & $\begin{array}{l}2 \cdot 2 \\
0 \cdot 9 \\
0 \cdot 9 \\
1 \cdot 0 \\
0 \cdot 8 \\
0 \cdot 5 \\
0 \cdot 4 \\
0 \cdot 7 \\
0 \cdot 9\end{array}$ & $\begin{array}{l}4 \cdot 9 \\
3 \cdot 5 \\
3 \cdot 2 \\
5 \cdot 5 \\
3 \cdot 7 \\
3 \cdot 6 \\
3 \cdot 3 \\
4 \cdot 0 \\
3 \cdot 1\end{array}$ & $\begin{array}{l}4 \cdot 3 \\
4 \cdot 3 \\
4 \cdot 3 \\
4 \cdot 3 \\
4 \cdot 3 \\
4 \cdot 3 \\
4 \cdot 3 \\
4 \cdot 3 \\
4 \cdot 3\end{array}$ & $\begin{array}{r}-0 \cdot 6 \\
0 \cdot 6 \\
1 \cdot 1 \\
-1 \cdot 2 \\
0 \cdot 6 \\
0 \cdot 7 \\
1 \cdot 0 \\
0 \cdot 3 \\
1 \cdot 2\end{array}$ & $\begin{array}{l}\overline{290} \\
\overline{310} \\
270 \\
\overline{2 \cdot 3} \\
\overline{1 \cdot 9}\end{array}$ \\
\hline
\end{tabular}

the Out-patient Department when he has appeared well, to be gaining weight and to be developing mentally to some extent. The plasma phenylalanine has remained high, and the urine gave positive reactions for phenylpyruvic acid.

Mental State. The results of mental tests are set out in Table 8 .

June 28,1955 (C.A. 59 weeks, M.A. 39 weeks, quotient 66). He could sit up and crawl, but could not stand. He was responsive to people, watching them and chuckling to games of 'peep-O'. He was beginning to help with feeding and making babbling sounds. He grasped well with finger and thumb, lifting the lid off a small box, and trying to take the cubes out of the box. He seemed very aware of his surroundings.

October 22, 1955 (C.A. 75 weeks, M.A. 45 weeks, quotient 60). He could now walk when led and cooperated slightly in dressing. He took bricks out of a small box, looked at picture books briefly and played with a 'dinky' car.

March 21, 1956 (C.A. 96 weeks, M.A. 57 weeks, quotient 59). After three months at home on a normal diet, with limited protein intake, he walked confidently with assistance. He would pull himself upright and stand alone. He waved 'bye-bye' and could be encouraged to play pat-a-cake. He could be credited with a few words and certainly made singing noises. He played ball with a definite throw to the examiner and pushed a toy car about. In exploring a room, he showed a more normal approach than the other affected children, persisting in attempts to open a cupboard where a toy was hidden. He was, however, showing a tendency to throw things down after a short interval and there was little perseverance abcut his actions.

\section{Discussion}

Biochemical Control. The most detailed studies were carried out with Michael, on a standard measured intake for 18 months. In this child, and in others, restriction of the phenylalanine to approximately $250 \mathrm{mg}$./day (15 mg./ $\mathbf{k g}$./day) sufficed to keep urine and plasma phenylalanine at normal levels and to allow normal growth (Fig. 5) provided that adequate calories were supplied (see below). This intake also permitted excessive growth rates in the earlier periods when the child had been grossly undernourished. Higher levels of phenylalanine intake resulted in a rise in the plasma level and in urinary excretion of phenylalanine, followed by the excretion of phenylpyruvic acid.

This level of intake also permitted normal accumulation of nitrogen in a growing child. In Michael, during the periods when calory intake was adequate (February-May, 1955, and November-May, 1956), mean positive nitrogen balances of $1 \cdot 16=0 \cdot 34$ and $1.60=0.52 \mathrm{~g}$. day were recorded. The average weight gain for this period was $8 \mathrm{~g}$. day and simultaneous measurements of the fat fold thickness (method of Edwards, Hammond, Healy, Tanner and Whitehouse, 1955) suggested that there was no gain in fat at these periods, and that therefore the weight

TABLE 8

RESULTS OF MENTAL TESTS IN ROBIN

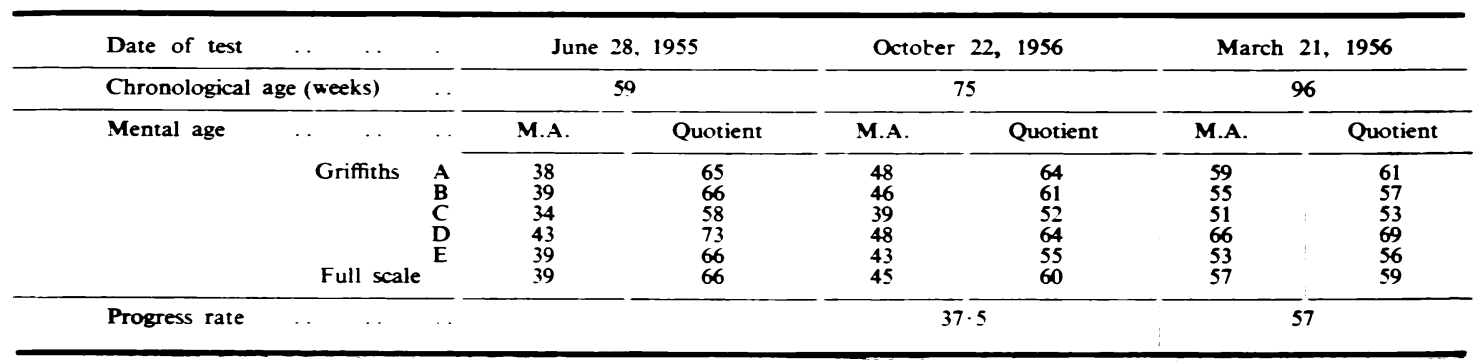


gain was largely protein. Information relating weight gain to nitrogen balance at this age could not be found in normal children, much less in those mentally backward whose energy requirements may be greater. However, the estimate of $3 \cdot 8 \%$ nitrogen in the fat-free body weight of a child aged $4 \frac{1}{2}$ (Widdowson, McCance and Spray, 1951) would suggest that the nitrogen gain: weight gain ratio of $1: 8$ in this child was unusually high, although as there are large standard errors for the mean daily nitrogen balance, the figures are not inconsistent. Clearly, further studies of this type are needed to interpret the significance of these findings, but they do indicate that protein and weight accumulation can take place at normal rates for prolonged periods even with such drastic limitation of phenylalanire intakes.

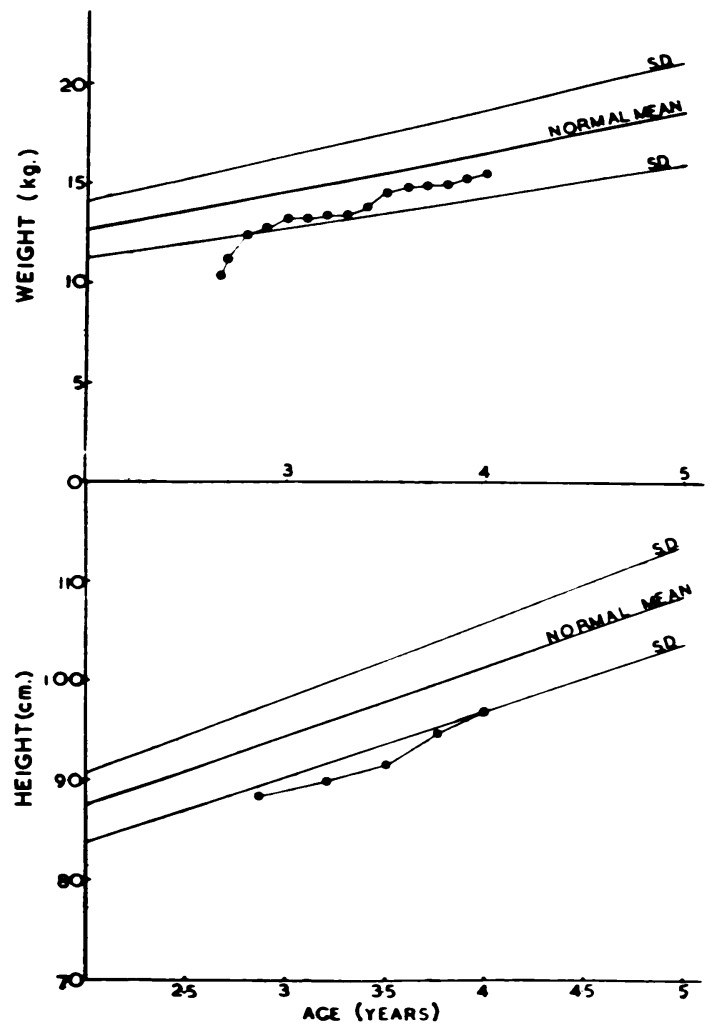

FIG. 5.-Weight and height records for Michael while on restricted diet compared with standard figures (Acheson et al., 1955).

The phenylalanine contents of body proteins are thought to be relatively constant, ranging from $2.6 \mathrm{~g}$. $/ 100 \mathrm{~g}$. protein (or per $16 \mathrm{~g}$. nitrogen) for keratins to $8.5 \mathrm{~g} . / 100 \mathrm{~g}$. for haemoglobin, with a mean value of $5.5=0.9$ (Block and Bolling, 1951).
During the periods of weight gain and positive nitrogen balance, the phenylalanine excretion in the urine rarely exceeded $10 \mathrm{mg}$. per day in the two cases studied in detail. The intake was approximately $260 \mathrm{mg}$./day, and if the whole of the retained amino-acid was utilized for body protein formation, the expected nitrogen balance would be $250 \times 16$

$\frac{-5,500}{5,16}=0.73 \mathrm{~g}$. day. This figure agrees well with those observed in Robin, but is lower than those found in Michael, although not at a significant level of difference. The important conclusion would appear to be that intakes of phenylalanine of $15 \mathrm{mg} . / \mathrm{kg}$./day are fully adequate to permit normal growth and formation of protein of normal composition in the body. This figure is substantially less than the estimated requirements for a normal adult, i.e., 20-22 mg./kg./day (Rose, 1949). No figures are available for growing children, but it is usually stated that their nitrogen and amino-acid requirements are greater. In the present series, the phenylalanine intakes were appreciably higher until it was realized that normal plasma levels could only be achieved with limitation of this degree. Woolf et al. (1955) gave intakes of 24 to $32 \mathrm{mg}$. $/ \mathrm{kg}$./day to three children and observed that the plasma phenylalanine was slightly above normal on semiquantitative estimation on paper. The figure of $15 \mathrm{mg} . / \mathrm{kg}$. is also indicated by the work of Armstrong and Tyler (1955) as the requirement for maintaining normal weight gain. It would seem preferable to keep the plasma and urine phenylalanine at normal levels, since in Michael it was observed that the rises which occurred during the periods of carbohydrate restriction were associated with slowing of his activities and with the appearance of abnormal indole derivatives in the urine.

The importance of the high carbohydrate intake needs to be stressed, since on two occasions when this was reduced the plasma and urine phenylalanine was increased. The effect was originally thought to be due to the reduction of calories from 110 to $95 \mathrm{cal}$. $\mathrm{kg}$. / day but as it did not follow a corresponding reduction in the calories supplied by fat, it seemed that a specific deficiency of carbohydrate was responsible. Normal children are said to require 80-100 cal. $/ \mathrm{kg}$. day. although there are few studies available for the younger ages. Satisfactory weight gain was observed in children of the age of 4 by Holt and Fales (1921) on $75 \mathrm{cal} . / \mathrm{kg}$./day and the level of $95 \mathrm{cal} / \mathrm{kg}$./day apparently required by Michael seemed unduly high. It has usually been considered that calory requirements are the prime consideration, and little attention has been paid to the proportions of fat and carbohydrate, other than 
that required to make the diet palatable. In Michael, the total nitrogen intake was low (4.8 g./day) and the average carbohydrate $230 \mathrm{~g}$./day, so the high requirements of the latter may be due to the limited intake or to nitrogen restriction. It also remains possible that these changes are brought about by calory limitation, if fat is not available readily as a source of energy. Under these circumstances, body protein is likely to be drawn upon for energy requirements, and the phenylalanine content of the latter cannot be metabolized satisfactorily by these patients, with a resulting rise in plasma and urine phenylalanine. There is as yet insufficient evidence to decide as to which of these possibilities is the correct interpretation of the observed facts.

The periods of biochemical abnormality emphasize the limitations of the ferric chloride reaction for phenylpyruvic acid in the urine as a test for adequate biochemical control, since it was often negative with appreciably raised plasma phenylalanine levels. It is, however, of great value as a diagnostic aid where the plasma phenylalanine appears always to be grossly raised. The microbiological assay determinations of plasma and urine phenylalanine levels appears therefore to be the only satisfactory index of control at present available. Boscott (1955) observed that o-hydroxyphenyl acetic acid appeared in the urine chromatogram on the two occasions on which the urine phenylalanine was rising in Michael, at a time when no other abnormalities were found; this may therefore be a more sensitive index of excess phenylalanine in the diet.

It has been suggested that abnormalities of tryptophane metabolism which have been observed in these cases (Armstrong and Robinson, 1954) may be responsible for the mental defect, since the association of plasma phenylalanine level and the degree of mental defect is clearly not simple. In Michael and Robin, these abnormal substances were found in the urine before treatment but were completely corrected by limitation of phenylalanine alone (Leyton, 1956). The hitherto unidentified 'blue spot' obtained with Ehrlich's reagent on paper chromatograms run in isopropyl alcohol-ammoniawater and in butanol-acetic-acid-water systems may also be a valuable index of early biochemical abnormality since it was present in Michael's urine before treatment and on both occasions when the biochemical control was inadequate. These abnormalities of tryptophane metabolism are also present in the two children seen with much higher I.Q. levels than any of the six described (Cases 7 and 8 in Fig. 7 and appendix) so that the precise relationship of the biochemical defects to the mental defect is still not clear.
Mental Changes. The long-term mental improvement in these children was limited, although it must be emphasized that except in the case of Michael, and for short periods in Pauline and Robin, the biochemical control was often inadequate by the standards defined. Two of the children showed a striking initial improvement with progress rates appreciably greater than before treatment. In 15 months Michael improved from a mental age of less than 6 months to a 12-month level of development, representing a gain of 30 weeks in 65 weeks. This was a rise of 9 points in the full-scale quotients, which represented an all-round improvement. Sheila gained five months of mental age in the first year of testing, the improvement being most marked in locomotion and manipulation and slowest in speech and personal-social aspects. This improvement was observed after she had been on the diet for 15 months and did not therefore represent an initial spurt at the beginning of treatment. Unfortunately, since the home conditions were complicated by the birth of another child, the dietary control became seriously inadequate, and her subsequent progress became much slower.

In two of the children there was little change on the restricted diet and no immediate difference followed when they were returned to normal intakes of phenylalanine. Both were over 5 years old when first treated and one was subject to numerous fits. The oldest child, Sylvia, showed an increase of motor activity on the diet but even after a year of fairly careful control, her behaviour was not sufficiently organized to permit formal testing. She presented a bizarre pattern of behaviour showing marked withdrawal similar to a psychotic patient.

The experience with these cases suggests that the age at which treatment is started is of the greatest importance. When one considers how much and how quickly the normal infant learns in the first two and three years of life, it is not surprising that the loss of earlier stages of development does not appear to be fully made up, in spite of satisfactory biochemical control. The development of Robin will be of interest in this connexion, for when first seen at the age of 13 months he was not seriously retarded, having a mental age of 39 weeks and a quotient of 66 . He appears to show a slightly falling progress rate, although it is at present clearly considerably more advanced than the majority of the children in the series. In several of the cases the history from the parents and welfare clinics suggested that deterioration in the mental state became more serious from 12 months onward. Some abilities that had begun to emerge before 1 year of age disappeared later in the increasing 
dissociation from their surroundings that is characteristic of these children. This evidence favours the suggestion that phenylketonuric children are normal at birth and that for some reason not yet identified the mental development becomes arrested after the first few months of life. That other systems may be involved is suggested by the abnormality of the teeth observed in these children. In three cases examined by histological methods this appears to be due to an enamel hypoplasia (McGregor and Manley, 1956); further investigation is proceeding into the nature of the abnormality.

In spite of the limited results achieved so far there is no doubt that considerable mental improvement has occurred in several of the children treated with phenylalanine restriction. This has been most striking in locomotor activities, four of the six having learned to walk during the period. All of them have shown changes in manner and bearing difficult to test formally.

Thus there has been an increased awareness of their surroundings and a decrease in the stereotyped movements and habits (rocking, head banging, teeth grinding, finger movements, etc.). Progress in speech has been relatively slow, none of the children learning much beyond the 12-month level. Several have progressed fairly quickly in manipulation (hand and eye scale), but have lagged in the use of this in actual tasks. The strikingly different rates of developnent in the different scales is well illustrated by Michael at the three monthly tests (Fig. 6).

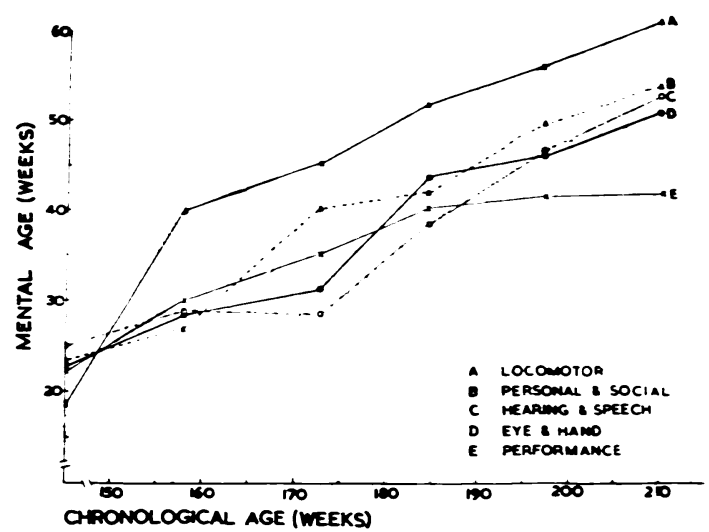

Fig. 6.-Graph showing the change in mental age on Griffiths scale with age in Michael.
One of the problems of treating mentally backward children is that of ensuring that they are given

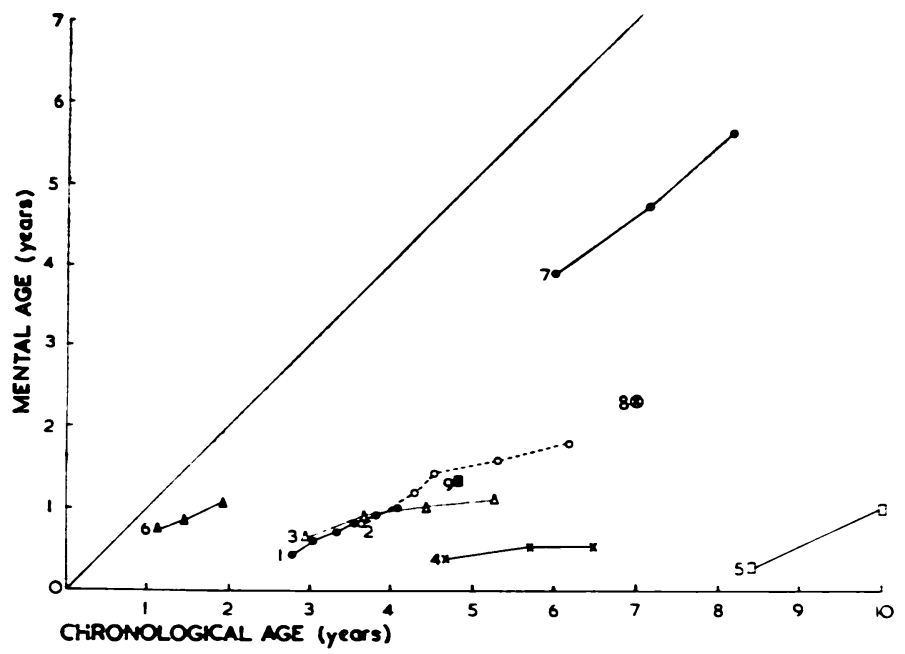

FKG. 7. Graph illustrating differences in initial mental age and progress in mean mental ages during treatment. Case 6 was treated for three months only, Cases 7 and 8 (see appendix) are untreated and have biochemical abnormalities as severe as initial findings in the remainder of the cases.

the experiences, affection and attention that they need at each stage of mental development (Buck, 1951). Whenever home treatment was adopted advice was given to the parents on management, but there was considerable variation in their ability to provide for these needs or to control the diet successfully. The children treated in hospital received considerable personal attention and were provided with toys, picture books and play pens as needed. Michael, in particular, benefited from this and responded with affection to the ward sister and others, and displayed remarkably intense emotional reactions. The hospital ward cannot supply all the varied learning experiences of the ordinary home and ways of effecting a greater variation in the child's environment while maintaining satisfactory dietary control must be considered in future work.

The wide range of initial development of children with this condition (see also Jervis, 1952) is of great importance in assessing the value of treatment and emphasizes the need for a standardized method of mental testing. Five of the children described had mental ages of less than 12 months with quotients placing them in the 'idiot' group. Two untreated children (see appendix) have considerably higher quotients (Fig. 7). Both these children show the same biochemical abnormality, both in respect of phenylalanine and tryptophane metabolites, and there is no suggestion of less severe biochemical 
abnormality than with the more severely affected children. It is, however, noteworthy that both children come from good homes, in which every effort has been made to foster their development. Such environmental factors may be of great importance in determining the final degree of improvement that can be obtained in the children treated on phenylalanine-low diets, especially when treatment is not started until after the first 12 to 18 months of life.

\section{Summary and Conclusions}

Six cases of phenylketonuria have been treated for periods of up to four years with phenylalanine restriction. In two, it has been possible to conduct detailed metabolic studies of weight, nitrogen balance, plasma and urine levels of phenylalanine, together with studies of the excretion of indole and phenolic compounds.

The abnormality of raised plasma and urine phenylalanine, together with the abnormal metabolic products of phenylalanine and tryptophane metabolism, can be completely corrected by sufficiently limiting phenylakanine intake to levels of $15 \mathrm{mg} . / \mathrm{kg}$./day. On this intake, normal weight gain and nitrogen balance and body protein formation can be attained for long periods.

High carbohydrate diets are essential in the treatment of phenylketonuric children on restricted phenylalanine intakes. An intake of $110 \mathrm{cals} . / \mathrm{kg}$./ day should be aimed at, and $70^{\circ} \%$ of this should be in the form of carbohydrate.

The practical difficulties of the management of the diets at home has led to inadequate control for long periods in the out-patients. Cases treated in hospital or in mental defective colonies have been satisfactorily controlled when the factors of optimal calory and phenylalanine intake have been ascertained.

Mental testing gave clear evidence in two cases of acceleration in the rate of development. In one case this was not maintained owing to inadequate dietary control at home; in the other, the acceleration has been maintained. This child, treated with strict dietary control for 15 months in hospital, has shown an advance in mental level of seven months with a slight but significant rise in I.Q.

In three cases, more limited changes were observed, in particular, the achievement of locomotion, increased awareness of surroundings and a diminution of mannerisms and habitual movements. Two of these were more than 5 years old when treated and the experience with them strongly suggests that treatment must be started at a much earlier age. The third case with good biochemical control failed to show marked improvement except in locomotion. Return to normal diet resulted in regression to pre-treatment behaviour in one case; a slight deterioration in behaviour in another; and little noticeable change in a third.

We wish to thank the physicians of the Children's Hospital, of St. Margaret's Hospital and the Chelmsley Hospital, Birmingham, for permission to publish details of cases under their care, and for their interest and encouragement. Many of the earlier studies of Cases 2, 3,4 and 5 were carried out by Dr. H. Bickel, when in receipt of a Medical Research Council grant at the Children's Hospital, and we wish to thank him for permission to include them in this report. We should like to acknowledge the help and interest of Professor J. R. Squire, Dr. R. F. Fletcher, Miss M. Crosskey and the staff of the Metabolic Research Unit, Little Bromwich Hospital, Dr. G. Leyton for the paper chromatography of indole compounds and Miss I. Guest for technical assistance.

\section{AP PEN D I X}

\section{Untreated Cases}

Case 7. Barbara was born on May 15, 1947. Her elder brother is a severely defective phenylketonuric at St. Margaret's Hospital and the diagnosis was only made during the routine testing of siblings of affected cases. She was normal at birth, sat up at 7 months, walked at 18 months and talked in sentences by the age of $3 \frac{1}{2}$. When she first attended school (age 5) she would not stay still but ran about the room continually. She had noisy tantrums and was not amenable to school discipline. She was, however, friendly, not aggressive, and responded well to individual attention. In May, 1953 (age 6), she had a mental age of 4 years 1 month on the Terman Merrill intelligence test.

She was admitted to the Children's Hospital under Dr. Gerrard in 1953 when the biochemical defect was found to be as severe as that observed in the other children. Her plasma phenylalanine level varied from 38 to $48 \mathrm{mg}$. $106 \mathrm{ml}$., with a considerably raised excretion of phenylalanine in the urine and with a daily excretion of 500 to $650 \mathrm{mg}$. of phenylpyruvic acid. She was placed on a low-protein diet giving about $700 \mathrm{mg}$. phenylalanine per day and has remained on this without appreciable change in the biochemical abnormality.

In 1955 after three years of schooling in a normal infant school, she was reported to be little trouble. She could take messages in school, played well with educational toys and was more independent. At home, she looked after herself in toilet matters, went to school unaccompanied and helped with home tasks. Mental testing showed that she was maintaining her status as a high-grade educationally subnormal child (I.Q. = 71) and was making satisfactory progress (see Fig. 6).

Case 8. Lynn, born on September 12, 1948, was regarded as normal until the age of 12-15 months when her general unawareness led to a diagnosis of mental defect. She sat up at about 10 months, and walked at the age of 2, although tended to fall easily. She talked in a limited way at the age of 3 . Thereafter, she made 
slow but steady progress and when first seen in November, 1955 (age 7 years 2 months), she had a mental age of 2 years 5 months on the Merrill-Palmer scale. She walked, ran and jumped and could climb stairs. She identified parts of her body and fed herself neatly with a spoon, though not with knife and fork. She asked to visit the toilet, and could communicate other needs. She would name toys and pictures and could repeat simple nursery rhymes. She had a number of mannerisms and rocked back and forth while talking or performing many activities. She was said to be fond of music and to be able to select her favourite records which she would listen to for long periods. She is at present attending an occupation centre and learning a few more simple activities.

She was admitted to the Metabolic Unit on April 4, 1956, when detailed studies were carried out on a measured normal dietary intake of phenylalanine (about $3.0 \mathrm{~g}$./day). The plasma phenylalanine level was $25 \mathrm{mg} . / 100 \mathrm{ml}$. and the urinary excretion of phenylalanine averaged $900 \mathrm{mg}$./day. In all, about $85^{\circ} \%$ of the phenylalanine administered in the diet was accounted for by retention in the body in the formation of protein or by excretion as phenylalanine, phenylpyruvic and phenyl-lactic acid (Jefford and Blainey). Abnormalities of tryptophane metabolism were also found in the urine and were qualitatively similar to those found in Michael, although there were quantitative differences. Unfortunately an attempt to put the child on to the phenylalanine-restricted diet were unsuccessful owing to her age and greater intelligence, the bitter taste of the hydrolysate being greatly resented. She was therefore discharged home on a low-protein diet and further observations of her progress are to be made.

\section{RefERENCES}

Acheson, R. M., Kemp, F. H. and Parfit. J. (1955). Lancet, 1, 691. Armstrong, M. D. and Robinson, K. S. (1954). Arch. Biochem. Biophys., 52, 287.

and Tyler, F. H. (1955). J. clin. Invest., 34, 565.

Bickel, H., Gerrard, J. and Hickmans, E. M. (1953). Lancet, 2, 812. Boscott, R. J. and Gerrard, J. (1955). Biochemistry of the Developing Nervous System. New York.

Blainey, J. D. (1956). Lancet, 1, 138.

Block, R. J. and Bolling, D. (1951). The Amino Acid Composition of Proteins and Foods, 2nd ed. Springfield, Ill.

Boscott, R. J. (1955). Personal communication.

Buck, P. (1951). The Child Who Never Grew. London.

Buehler, C. and Hetzer, H. (1935). Testing Children's Development. London.

Dalgliesh, C. E. (1955). J. clin. Path., 8, 73.

Doll, E. A. (1935). The Vineland Social Maturity Scale. Minneapolis.

Edwards, D. A. W., Hammond, W. H.. Healy, M. J. R., Tanner, J. M. and Whitehouse. R. H. (1955). Brit. J. Nutr., 9, 133.

Gesell, A. and Amatruda, C. S. (1941). Developmental Diagnosis. New York.

Griffiths, R. (1954). The Abilities of Babies. London.

Henderson, L. M. and Snell, E. E. (1948). J. biol. Chem., 172, 15.

Holt, L. E. and Fales, H. L. (1921). Amer. J. Dis. Child., 22, 371.

Jefford, A. and Blainey, J. D. To be published.

Jervis, G. A. (1952). Proc. Soc. exp. Biol. (N.Y.), 81, 715.

Leyton, G. (1956). Personal communication.

Penrose, L. and Quastrel, J. H. (1937). Biochem. J., 31, 266.

Penrose, L. and Quastrel, H. Hanley, E. B. (1956)" 266. Communication.

Rose, W. C. (1949). Fed. Proc., 8, 546.

Terman, L. M. and Merrill, M. A. (1937). Measuring Intelligence. London.

Widdowson, E. M., McCance, R. A. and Spray, C. M. (1951). Clin. Sci. 10, 113 . Woolf, L. I., Griffiths, R. and Moncrieff. A. (1955). Brit. med. J., 